Papers and Proceedings of the Royal Society of Tasmania, Volume 110, 1976

(ms. received 6.11.1975)

\title{
THE SIGNIFICANCE AND PROVENANCE OF STROMATOLITIC CLASTS IN A PROBABLE LATE PRECAMBRIAN DIAMICTITE \\ IN NORTHWESTERN TASMANIA
}

by B.J. Griffin, University of Tasmania

and W.V. Preiss, Department of Mines, South Australia

(with three text-figures and six plates)

\section{ABSTRACT}

Two types of stromatolitic dolomite boulders occur in a diamictite of possibly late Precambrian age in northwestern Tasmania; they are the oldest Tasmanian fossils so far recorded. The first type comprises dark grey dolomites containing the stromatolite Baicalia cf. B. burra, generally well preserved. The remainder are pale grey rather recrystallised dolomites containing stratiform and columnar-layered stromatolites. Their diagenesis and intrusion by dolomite veins preceded the erosion and redeposition of the clasts into the diamictite.

The diamictite contains no diagnostic evidence of glaciation though a glacial origin cannot be definitely excluded. A debris flow mechanism of deposition is favoured.

There is no proof in the material examined that either the well preserved Baicalia specimens or the recrystallised stromatolitic dolomites, occurring in clasts in the diamictite, were derived from the Smithton Dolomite. The occurrence of Baicalia cf. B. burra is consistent with a late Precambrian age of the source rocks, and close comparisons can be made with the Skillogalee Dolomite of South Australia.

\section{INTRODUCTION}

Stromatolitic clasts have been found by one of us (B.J.G.) during geological mapping in a possibly late Precambrian diamictite overlying the Smithton Dolomite of northwestern Tasmania. Six samples collected from three separate localities (fig.1) on the BURNIE sheet area were examined by W.V.P. This paper discusses the evidence for the source of the diamictite and the significance of the stromatolites.

\section{REGIONAL GEOLOGY}

The geology of northwestern Tasmania has been summarised by Gee (1968) and by Turner (1973 unpublished), and of the Trowutta area by Longman and Matthews (1961).

Basic dykes of the Cooee Dolerite, dated by the $\mathrm{K}$-Ar method at $720 \mathrm{~m} . \mathrm{y}$. (Richards, J.R. in Solomon \& Griffiths 1974, p.21), intrude the Precambrian Cowrie Siltstone. The Cowrie Siltstone is in turn unconformably overlain to the north-east of Trowutta (fig. 1) by a thin quartz sandstone and conglomerate sequence, followed conformably by the Smithton Dolomite, a $1500 \mathrm{~m}$ thick dolomite-chert sequence. As no confirmatory $\mathrm{Rb}-\mathrm{Sr}$ data are available, this date should probably be regarded as only a minimum age. The dykes are considered to be syntectonic with the Penguin Orogeny which has deformed the Cowrie Siltstone (Gee 1971). This deformation does not extend into the Smithton Dolomite, which is therefore probably younger than the dykes, but further geochronology would be desirable to fix the age of these. 


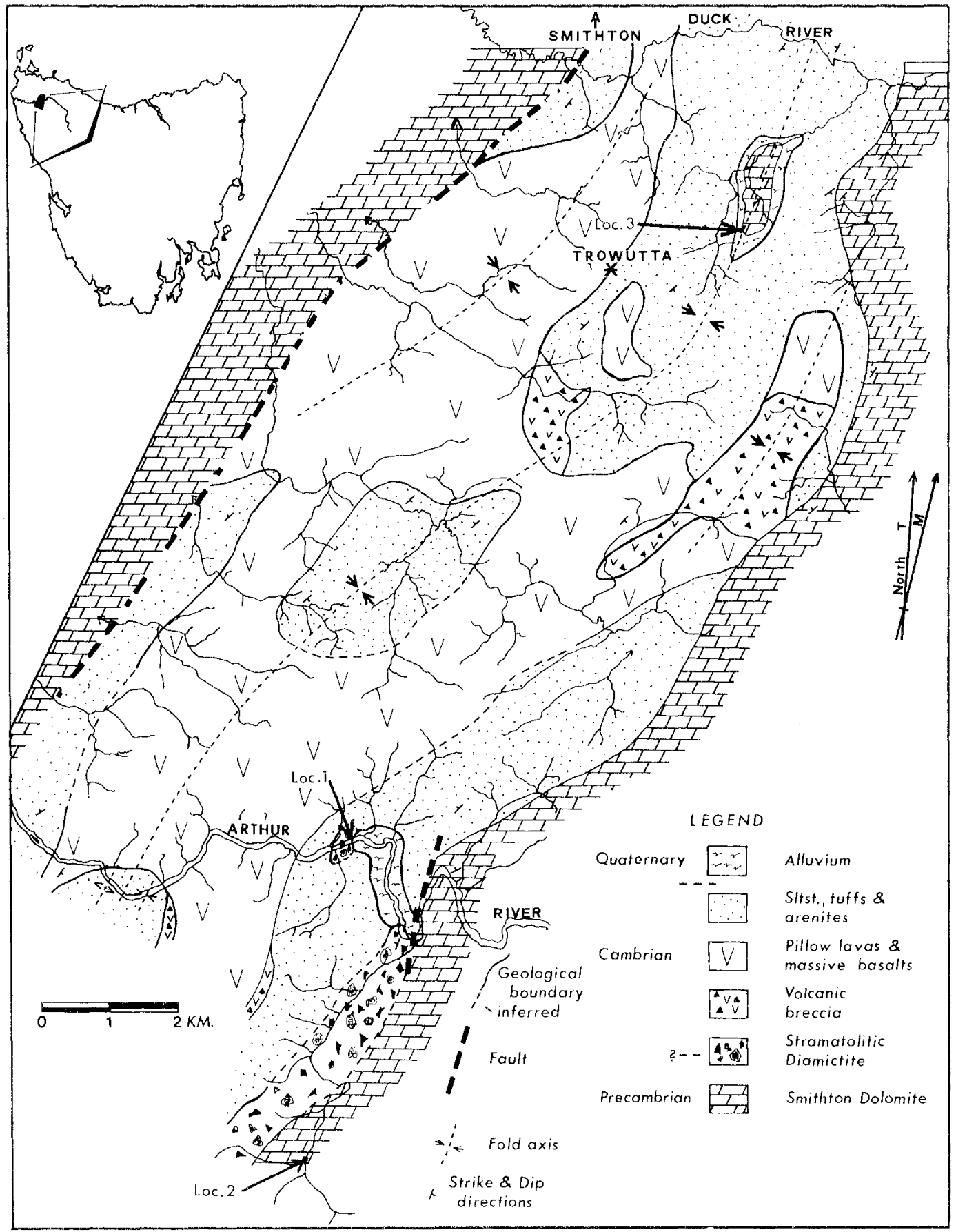

Fig. 1. Geological locality map of Trowutta area, northwestern Tasmania. The specimen localities are as follows:- (1) Spec. No. 94097; (2) Spec. Nos. 94099-94119; (3) Spec. No. 94098. 


\section{B.J. Griffin and W.V. Preiss}

The Smithton Dolomite, mapped by B.J.G., consists of irregularly a1ternating beds of massive dolomite, oolitic dolomite, and horizons with desiccation cracks and stratiform stromatolites. It is overlain by a diamictite with stromatolitic clasts. In the Trowutta area (fig. 1) the diamictite is overlain by a sequence approximately $1500 \mathrm{~m}$ thick of interbedded tholeiitic lavas and dykes, mudstone and siltstone, with minor breccia and tuff. This sequence is correlated with the Dundas Group and is thus presumed to be Cambrian in age (Carey \& Scott 1952). Such a correlation is supported by the presence of a late Middle Cambrian trilobite fauna (Gulline 1959) in a sedimentologically similar sequence that occurs ten kilometres to the west at Christmas Hills.

The diamictite is lithologically comparable to the Cottons Breccia of King Island, which possibly overlies unconformably granites that are 715-750 m.y. old, but this is not certain, and no fossils have been found in the overlying sediments (Jago 1974). Jago (1974) also presented arguments for and against a glacial origin of the Cottons Breccia.

The base of the Smithton Dolomite is regionally transgressive (Williams \& Turner 1974). Three possible relationships between sections of the Smithton Dolomite and the diamictite at Trowutta and at Black River are shown in figure 2, and al1 of these are consistent with the present evidence.

\section{TROWUTTA BLACK RIVER}

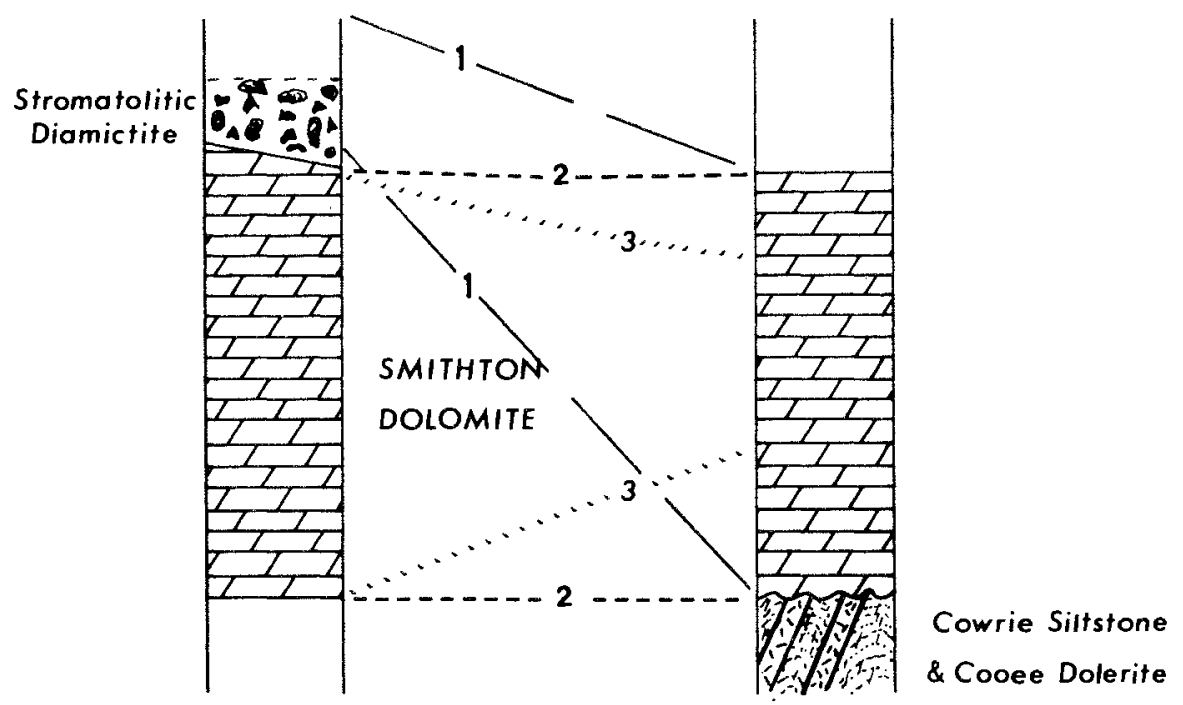

Fig. 2. Alternative correlations between sections at Trowutta and Black River. 
A11 Cambrian and older rocks in the Trowutta area have been affected by a low grade regional hydrothermal metamorphism. Most affected are the Cambrian tholeiitic lavas, which have been extensively spilitised with the development of prehnite-pumpellyite assemblages. The Smithton colomite has been variously metamorphosed on a local scale, and graditions from virtually unaltered massive dolomite to coarsely recrystallised dolomite may be observed in some areas over a distance of five metres. There is also partial or total replacement by chert, but it is not certain how much of this is a diagenetic effect and how much is due to metamorphism..

\section{THE NATURE AND ORIGIN OF THE DIAMICTITE}

The diamictite is texturally immature with clasts up to two metres long set in a matrix-supported framework. The clasts are generally unsorted and vary in shape from angular to subrounded with low degrees of sphericity (plate 1, figs. a, b). A crude stratification was observed in one outcrop, represented by poorly developed graded bedding repeated over one metre intervals. No other large scale sedimentary structures were observed.

The clasts are either dolomite or chert, the latter forming only $5-10 \%$ of the clast population. Of the dolomite clasts, $10-15 \%$ contain stromatolite structures, while the remainder are simply fine to medium-grained massive dolomites. The clasts range in size from the observed maximum of two metres in length to silt-sized particles. There is no apparent bias in clast size distribution. The matrix of the rock may be considered as the material of grain size less than $0.2 \mathrm{~mm}$, and this fraction may compose up to $25 \%$ of the rock. Included in the matrix fraction are small ooids, often broken into radial segments, which resemble ooids present in parts of the Smithton Dolomite.

The textural immaturity and other features of the diamictite would be consistent with either a glacial or mudflow mechanism of deposition. The absence of glaciated (striated or facetted) clasts, the relatively restricted range of lithologies represented by t-e clasts, and the presence of crude graded bedding in one outcrop, tend to favour a submarine mass transport mechanism, although a glacial contribution cannot be definitely excluded. The source of the clasts was massive stromatolitic and cherty dolomite, and evidence is presented below that these clasts were lithified and veined prior to redeposition into the diamictite. On the other hand, the radially fractured individual ooid grains suggest the reworking of unconsolidated sediment. It is possible therefore that there were at least two separate sources for the detritus in the diamictite.

\section{DESCRIPTION OF STROMATOLITE SAMPLES}

Two types of stromatolitic carbonate are present in the assemblage of clasts examined by one of us (W.V.P.)

(1) Specimens 94097, 94098, and 94102-94119 are minimally recrystallised dark grey dolomites, in part siliceous, and all containing the same type of well preserved columnar stromatolites

(2) Specimens 94099,94100 and 94101 are paler grey, more recry-tallised dolomites in which the stromatolitic lamination is only partially preserved. The

Smithton Dolomite specimen (94120) is coarsely recrystallised and could be of

higher metamorphic grade than the other samples.

The specimens described herein are stored in the collections of the Department of Geology, University of Tasmania. 


\section{B.J. Griffin and W.V. Preiss}

Group BATCALIA Krylov, (1963:64)

Baicalia cf. B. burpa Preiss (1972:80)

Material: Specimens 94097, 94098 and 94102-94119.

\section{Description}

Mode of Occurrence: This is unknown for the specimens provided since the stromatolites occur only in clasts and have not been located in situ. [Baicalia burra from the Flinders Ranges of S.A. occurs in thin tabular and domed biostromes, rarely in small discrete bioherms. Growth commences either from flat-laminated stromatolites, or on erosional surfaces. (Preiss 1972, p.81)]

Column Shape and Arrangement: Columns are tuberous, varying from sub-cylindrical to irregularly elongated, with round, oval and irregular traverse sections. Diameter of columns varies from 15 to $100 \mathrm{~mm}$. Columns frequently show rapid expansions and constrictions (figs. 3a,d,e; p1s. 2a; 3a; 5). The orientation of columns varies from vertical to inclined, in places nearly horizontal for short distances. Column axes are generally curved (fig. 3a; P1. 2a).

Branching: The samples are of insufficient size to be fully representative of branching style (Baicalia burra shows a large range of variation of branching styles). Branches illustrated in reconstructions are slightly and markedly divergent (fig. 3a; PL. 2a).

Margin structure: The lateral surface of columns is generally smooth but in places short peaks overhang the margin. Generally laminae approach the margin at a high angle, and terminate without appreciable thinning. Locally the laminae thin and coat the margin so as to form a patchy wall (e.g. pl. 5a, Specimen 94118); this occurs only where the laminae are steeply convex.

Lamina. Shape: Lamina shape is mostly gently to moderately convex, but varies even in single columns from very gently convex to steeply convex. Seventy percent of the laminae measured have ratios of $\mathrm{h} / \mathrm{d}$ between 0.2 and 0.5 . As with Baicalia burra, the mode falls in the interval $0.3-0.4$. The laminae are very smooth, and of even, uniform curvature, except where they overlie contemporaneous erosional surfaces (micro-unconformities). The shape of laminae shows a high degree of inheritance, except at microunconformities, which are common in all specimens. Micro-unconformities are observed to have a maximum erosional relief of about a centimetre. Some typical lamina shapes are illustrated in Fig. 3b.

Microstructure: The lamination is generally well preserved and comprises alternating very distinct, continuous light and dark laminae. This type of microstructure is termed "banded". Both types of laminae are continuous across the full width of columns, except where cut by micro-unconformities. The dark laminae consist of micritic ferroan dolomite, enriched in organic matter, and partly pyritic. They represent probable original successive sheet-like algal mats in which carbonate mud was either trapped or precipitated by algal filaments. Their thickness varies from about $30 \mu \mathrm{m}$ to $20 \mu \mathrm{m}$, but in places thicker dark bands, up to a millimetre thick consist of sets of very fine light-dark lamination pairs. These sets are termed "macrolaminae" (e.g. p1. 5a). No algal filaments are preserved in the dark laminae, however there are streaky, wispy concentrations of organic matter within them, generally parallel to the lamination but finely wavy and locally oblique. These resemble the lamination fabrics of certain dolomitic stromatolites which are microfossiliferous where silicified. It is suggested that this fabric results from the trapping of carbonate mud by an algal mat whose filaments lie sub-parallel to the lamination. The presence of recumbently overfolded sections of some laminae suggests that they were cohesive, of rubbery consistency (as if often observed with Recent algal mats) and only loosely attached to the underlying laminae. The presence of rounded carbonate grains of fine sand size (detrita1?) in some dark laminae, with the wispy concentrations of organic matter draped around them, is suggestive of trapping and binding action by algal filaments. However, precipitation of carbonate within the algal mats, due to changes in microenvironment caused by algal photosynthesis, is known in Recent mats and was probably 


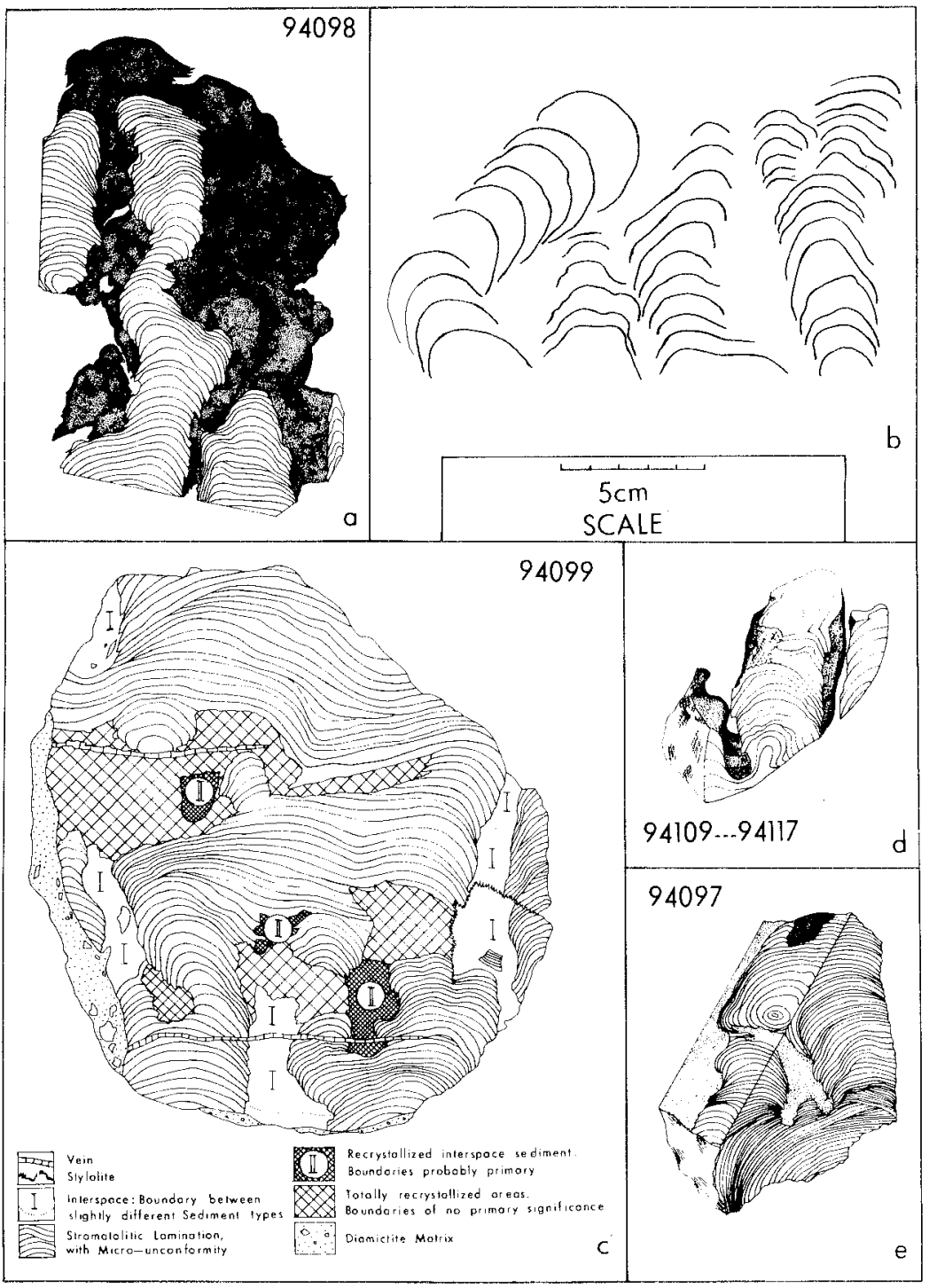

Fig. 3. Stromatolites from the Smithton-Trowutta area, Note: The 50 mm scale bar applies to all drawings.

(a) Reconstruction of Baicalia cf. B. burra, specimen No. 94098; (b) representative examples of lamina shapes of Baicalia cf. $B$. burra; (c) boulder of recrystalised stromatolitic dolomite in diamictite matrix; (d) drawn from acetate peel; specimen No. 94099; reconstruction of Baicalia cf. B. burra using serial slabs, specimen Nos. 94109-94117; (e) sketch of Baicalia cf. $B$. burra; the lightly stippled area represents interspace sediment; note the pronounced micro-unconformities; specimen No. 94097 


\section{B.J. Griffin and W.V. Preiss}

important in the Precambrian (Monty 1973). There is no evidence as to whether trapping or precipitation was the dominant factor in the building up of these stromatolites.

The intervening light laminae consist of clear sparry dolomite. Unlike the dolomite of the dark laminae, it remains unstained by potassium ferricyanide and is therefore a relatively pure dolomite. The light laminae are of xenotopic, roughly equigranular texture, of grain size 20 to $60 \mu \mathrm{m}$. Their thickness varies from 50 to $500 \mathrm{~m}$ and in places gradations can be observed at the tops of dark laminae which suggest that the boundaries have been slightly recrystallised (pls. 5a; 6a, b).

Relationships at micro-unconformities (pls. 5a; 6a, b) suggest that the eroded surface of the stromatolite was somewhat irregular and that the overlying lamina was draped over the irregularities. This left void spaces whose sparry infilling is often continuous with the sparite of the light laminae. It is possible that the light laminae were originally entirely void, being formed by the lifting of the growing surface mat from its substratum. Where one light lamina truncates an underlying light lamina the evidence is equivocal; in places the sparite is continuous between the two, and in other places, the younger sparite is distinct and demarcated from the older by lines of impurities or changes in texture (pl. 5a). This evidence could be interpreted in two ways:-

(1) The sparite is an open-space filling which was precipitated in place soon

after the formation of void, and was itself subject to penecontemporaneous erosion.

(2) The sparite represents a primary lamina of relatively pure carbonate which

was later locally subject to recrystallisation.

Interspaces: These are filled everywhere with randomly packed intraclast grainstone, The intraclasts are small broken fragments of the algal mats forming the columns; they similarly consist of ferroan dolomite. In places at column margins, gradations can be observed where the dark laminae have spalled off the column and were preserved in the process of being incorporated into the interspace sediment. There are also larger angular fragments eroded from the stromatolite in which the sparry laminae are fully developed. In this case at least, they pre-date pene-contemporaneous erosion. In places, there are subrounded pellets, $0.1-0.2 \mathrm{~mm}$ in diameter, probably themselves comminuted intraclasts. The intraclasts are cemented by, and partly recrystallised to sparry pure dolomite; in places there are two generations of cement, an earlier drusy and a later blocky phase.

The interspaces appear to contain no micrite or other muddy sediments. The winnowed, grain-supported nature of the sediment suggests accumulation under high energy conditions.

Secondary Alterations :

(1) Penecontemporaneous. Like the stromatolites of the Skillogalee Dolomite, South Australia, these are entirely dolomitic. It is uncertain whether this reflects syndepositional dolomitisation of 1 ime mud sediments, perhaps associated with dolomitic cementation, or whether the muds that were trapped by the algal mats were already colomitic. The total absence of remnant calcite and extremely fine texture of the dolomite in these cases argue against a later diagenetic origin of the dolomite. Indeed the excellent preservation of fine lamina detail is suggestive of the original sediment being dolomite. Actively growing algal mats were probably only loosely attached to their substrata, and the void spaces were filled with sparry dolomite at an early stage, in any case often prior to contemporaneous erosion, which may have taken place during storms.

(2) Diagenetic. The stromatolites are patchily silificied in some specimens. Unlike the black cherts replacing carbonate in the Skillogalee Dolomite however, the silica here has not preserved the detailed primary structures well. The chert is medium grey in colour and of microcrystalline, xenotopic texture, grain size $10-15 \mathrm{~mm}$. It tends to follow the lamination broadly, preferentially replacing either the sparry or the dark laminae but also transgressing across the lamination in detail. The chert 
is very patchy and does not appear to be prospective for finding microfossi1s; however if any samples could be found which are completely silicified to a dense black chert with well preserved lamination, these would warrant careful examination.

Partial recrystallisation of dolomite has been mentioned above. This has affected both light and dark laminae in certain cross-cutting areas. Incipient recrystallisation of some parts of dark laminae has produced very minor grumous textures. Locally, irregular vughs (possibly due to solution) are partially or wholly filled with coarse drusy quartz (P1. 7a).

\section{Comparisons}

The stromatolites readily fall into the group Baicalia on the basis of column shape, branching style, surface morphology and microstructure. They particularly resemble Baicalia burra, especially in specimens from the Willouran Ranges, S.A. where the preservation of the lamination and the nature of the interspace sediments are closely comparable. A lithological difference is that the dolomite forming the Skillogalee Dolomite stromatolites is not notably ferroan. The nearest known occurrence of South Australian Baicalia burra is in the vicinity of Burra, but here the interspace sediments are dominantly dolomicrites and the preservation is poorer due to low grade regional metamorphism. Because of the mode of occurrence and large-scale structure of the Tasmanian stromatolites is not known, they are referred to Baicalia cf. B. burra.

\section{Unclassified Poorly Preserved Stromatolites}

Specimen No. 94120 (Smithton Dolomite):- This is a rather coarsely recrystallised, medium grey, stratiform-stromatolitic dolomite (average grain size about $0.1 \mathrm{~mm}$ ) . The lamination is preserved only in a general way by slight contrasts of pigmentation but without marked changes in grain size across lamina boundaries. Near its natural weathering surface the specimen shows selective leaching of some laminae. It is cut by very coarse dolomite veins and irregular nodules. The primary microstructure is very poorly preserved and is therefore impossible to compare with that of other stromatolites (pl. $2 \mathrm{~b})$.

Specimens 94099 and 94101 are pale to medium grey dolomites of a degree of recrystallisation intermediate between that of the Baicalia specimens and that of specimen 94120. A peel made from 94099 is illustrated diagrammatically in figure $3 \mathrm{c}$. In the areas of the peel in which primary stromatolitic lamination is preserved the microstructure may have originally been banded but is now far more recrystallised than that of the we11 preserved specimens. The dark laminae are wispy, lenticular, about 0.1 $\mathrm{nm}$ thick; light laminae are more continuous, up to $1 \mathrm{~mm}$ thick, and consist of $20-30 \mu \mathrm{m}$ grain size xenotopic dolomite, and in part ferroan dolomite.

The gross morphology is only partly columnar, but passes upwards into stratiform stromatolites. Over large areas the primary boundaries of columns are obliterated by recrystallisation; where margins are preserved they are unwalled but relatively smooth. Interspaces are filled with more or less recrystallised dolomite (originally micritic?) incorporating both structureless intraclasts and laminated stromatolite fragments. In places the interspace sediments are completely recrystallised to a very coarse, sparry mosaic. Bedding is locally expressed in the interspaces by s!ight changes in silt content (fig. 3c). Dolomite veins and stylolites cut the whole rock and post-date its lithification. They definitely pre-date the erosion and redeposition of the clast.

\section{SIGNIFICANCE OF THE STROMATOLITES}

The following facts may be stated with some confidence:-

(1) The stromatolitic clasts were derived from the erosion of a completely lithified dolomite, appreciably older than the diamictite containing the clasts. 
they are not intraformational.

(2) The well preserved stromatolites closely resemble Buicalia burra known from the Skillogalee Dolomite of Torrensian age from the Adelaide Ceosyncline.

(3) Baicalia burra is similar to $\mathrm{k}$. maica Nuzhnov, known from the uppermost Middle Riphean of the U.S.S.R., dated about $950-1000 \mathrm{~m} . \mathrm{y}$.

(4) Baicalia has so far never been reported from rocks younger than about $700 \mathrm{~m} . \mathrm{y}$.

Any interpretation of these facts is however, hihghly tentative and controversial. It must be based on certain assumptions which should be clearly stated:

(1) that individual stromatclite taxa have restricted timc-ranges. (Opinion on this issue is still divided).

(2) that the time ranges of the taxa that have been worked out in the U.S.S.R. an be duplicated aiso on other continents. (There is an indication that they may be duplicable, but this is not yet proven).

(3) that the tjme ranges of specific stromatolite forms will be the same as those of very closely related, but distinguishable forms.

These three assumptions would lead to the conclusion that both the Skillogalee Dolomite, and the dolomite from which the clasts were eroded, are about $1000 \mathrm{~m} . y$. old. The following arguments should be weighed against this conclusion:-

(1) The data of Cooper and Compston (1971), if proved correct, would indicate that the Skillogalee Dolomite is younger, perhaps considerably younger, than $870 \mathrm{~m} . \mathrm{y}$. This would also affect the age interpretation of the Tasmanian stromatolites if a correlation with the Skillogalee Dolomite is maintained.

(2) Baicalia burra is not strictly comparable to any Russian stromatolite taxa at form level. Therefure the time ranges need rot necessarily be identical. Other forms of Baicalix do range up into the Late Riphean (950 to $680 \mathrm{m.y}$.) in the U.S.S.R. and North Africa.

\section{CONCLUSIONS}

Recent work by B.J.G. has shown that a major hydrothermal metamorphic event occurred after the eruption of the Cambrian volcanics. The "spilitisation" of the volcanics to prehnite-pumpellyite assemblages in the Trowlta are: has affected rocks as far as the coast at Smithton and south to the Arthur River, indicating metaiorphism of regional extent. The metamorphic effects may be traced down into the Smithton Dolomite, which has been variously recrystallised, as discussed above. The variable degree of recrystallisation in the clasts is comparable to that seen in the Smithton Dolomite, and cannot therefore be used to argue against the Smithton Dolomite being a source of the clasts in the diamictite.

However, the stromatolitic clasts show evidence of being lithified, veined, and affected by stylolitic pressure solution prior to erosion and redeposition into the diamictite. On the other hand, fractured individual ooids, similar to ooids fourid in the Smithton Dolomite, suggest reworking of unconsolidated or only poorly conso! i. dated sediment from the Smithton Dolomite into the diumictite. The Smithton Dolonite contains stratiform stromatolites, but Baicalia cf. B. burra, found in the clasts, has not been located in it. Therefore there is the possibility of at least two sources for the constituents of the diamictjte: unconsolidated Smithton Dolomite and consolidated older dolomites. The stromatolites themselves do not provide any evidence that the Smithton Dolomite was the source of the stromatolitic clasts.

The identification of Baicalia cf. burra is consistent with late precambrian age for the source of the clasts. If cortain assumptions are accepted, the range :...y be less than about $1000 \mathrm{~m} . \mathrm{y}$. and greater than about $700 \mathrm{~m}$.. The clasts could have been derived from a correlative of the Skillogalee Dolomite of South Australia, or a southerly extension of it. If their source was local, it would support an origin by a debris flow mochanism for the diamictite. On the other had, a distant source such as 
the Skillogalee Dolomite would favour a hypothesis of glacial transport for at least some of the clasts. At this stage, it is not possible to resolve conclusively which of these alternatives is correct. The Smithton Dolomite acted as a local source of relatively unconsolidated detritus reworked into the diamictite in addition to the lithified stromatolitic clasts.

\section{ACKNOWLEDGEMENTS}

The residents of the Trowutta area are thanked for their help during the mapping of the area. Mr. M.R. Banks and Dr. E. Williams are also thanked for their discussions and criticisms of this paper. The paper is published with the permission of the Director of Mines, South Australian Mines Department.

\section{REFERENCES}

Cooper, J.A. E Compston, W., 1971: Rb-Sr dating within the Houghton Inlier, South Australia. J. geol. Soc. Aust., 17 (2), 213-219.

Carey, S.W. \& Scott, B. 1952: Revised interpretation of the geology of the Smithton district. Pap. Proc. R. Soc. Tasm., 86, 63-70.

Gee, R.D., 1968: A revised stratigraphy for the Precambrian in northwest Tasmania. Pap. Proc. R. Soc. Tasm., 102, 7-10.

, 1971: Geological Atlas 1 mile series. Zone 7 sheet 22 (8016S). Table Cape. Explan. Rep. geol. Surv. Tas., 10.

Gulline, A.B., 1959: The underground water resources of the Smithton district. Undergr. Wat. Supply Pap. Tasm., 5 .

Jago, J.B., 1974: The origin of Cottons Breccia, King Island, Tasmania. Trans. R. Soc. S. Aust., $98(1), 13-28$.

Longman, M.J. \& Matthews, W.L., 1961: Geology of the Bluff Point and Trowutta Quadrangles. Tech. Rep. Dep. Mines. Tasm., 6, 48-54.

Monty, C.L.V., 1973: Precambrian Background and Phanerozoic History of Stromatolitic Communities, an overview. Annzs. Soc. geoz. Belg., 96, 585-624.

Preiss, W.V., 1972: The systematics of South Australian Precambrian and Cambrian stromatolites. Part 1. Trans. R. Soc. S. Aust., 96 (2), 67-100.

Solomon: M. E Griffiths, J.R., 1974: Aspects of the early history of the southern part of the Tasman Orogenic Zone in A.K. Denmead, A. Tweedale and A.F. Wilson (Ecls), THE TASMAN GEOSYNCLINE, Geol. Soc. Aust. $409 \mathrm{p}$.

Turner, N.J., 1973: Precambrian geology of Tasmania. (abstract). International Union of Geological Sciences, Subcommission on Precambrian Stratigraphy - Adelaide Meeting, May 1973, unpublished.

Williams, E. \& Turner, N.J., 1974 : Geological atlas 1:250 000 series. Sheet No. SK-55/3. Burnie. Explan. Rep. geoz. Surv. Tasm. 


\section{PLATE EXPLANATIONS}

Plate 1 : (a) Polished surface of hand specimen of stromatolitic diamictite showing angularity and size range of clasts.

(b) Thin section viewed in transmitted light showing angularity and size range of clasts, one of which (large and central) is of a stromatolitic fragment.

Plate 2 : (a) Slab of Baicalia cf. B. burra (spec. no. 94098). The columns have been outlined in Indian ink and reference lines drawn at right angles on the slabs to facilitate three-dimensional reconstruction (see fig. 2a). Scale is graduated in millimetres.

(b) Polished slab of Smithton Dolomite (spec. no. 94120), consisting of stratiform stromatulites with poorly preserved lamination.

(c) Broken fragment of stromatolitic boulder containing Baicalia cf. $B$. burra spec. no. 94102). The relatively darker laminae have been stained deep blue by potassium ferricyanide, indicating that they are composed of ferroan dolomite.

Plate 3 : (a) Broken fragment of a stromatolitic boulder illustrating weathered surface.

Baicalia cf. B. burra. (spec. no. 94104-94105).

(b) Broken fragment of a stromatolitic boulder illustrating the distinctly banded microstructure of Baicalia cf. B. burpa on weathered surface. (spec. no. 94109 ).

Plate 4 : (a) Stained acetate peel of partially silicified dolomite boulder containing Baicalia cf. B. burra. (spec. no. 94097). The dark laminae are composed of ferroan dolomite, stained deep blue by potassium ferricyanide (i.e. scale in centimetres).

(b) Etched slab of the same specimen from which the acetate peel was taken. The irregular very dark patches (which appear blank on the peel) are solicified. (Scale in millimetres).

Plate 5 : (a) Thin section of Baicalia cf. B. burra (spec. no. 94118) illustrating the banded microstructure of alternating ferroan dolomite dark laminae and sparry pure dolomite laminae, micro-unconformities and local development of a wall at column margin. (in lower right corner). (Scale in millimetres).

(b) Large stained acetate peel of recrystallised stromatolitic boulder in diamictite matrix (dark area at right). The structures visible are illustrated in fig. 3c. (Scale bar in centimetres).

Plate 6 : (a) Thin section of Baicalia cf. B. burra illustrating banded microstructure with micro-unconformities. (Scale in millimetres). spec- no. $94119 \mathrm{~b}$ ).

(b) Stained acetate peel of another part of the same specimen (94119a). The dark laminae are composed of ferroan dolomite. In places laminae appear to be overfolded suggesting a cohesive flexible consistency of the algal mats. (Scale in millimetres). 
122

Stromatolitic clasts in Precambrian diamictite, N.W. Tasmania

A.
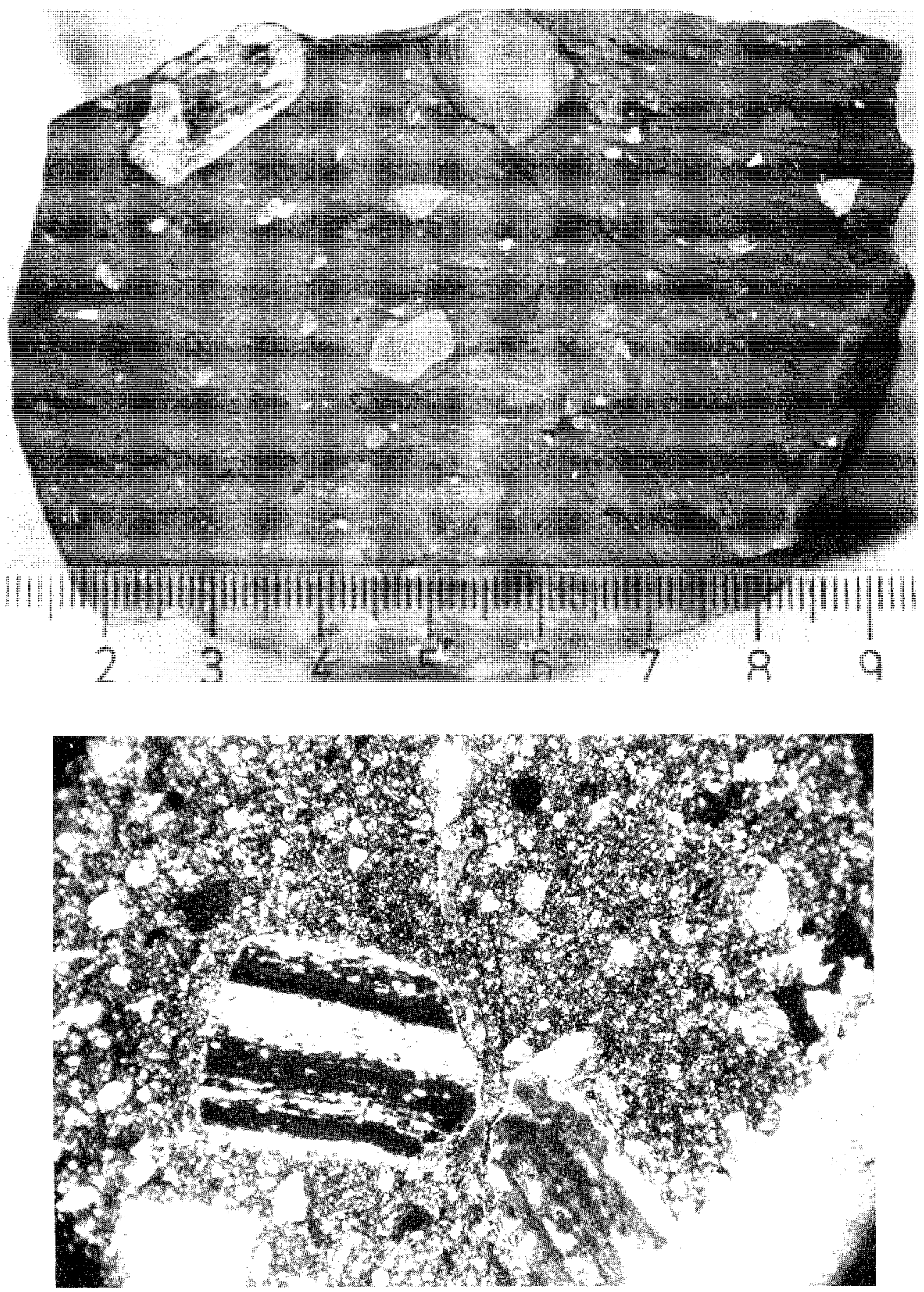

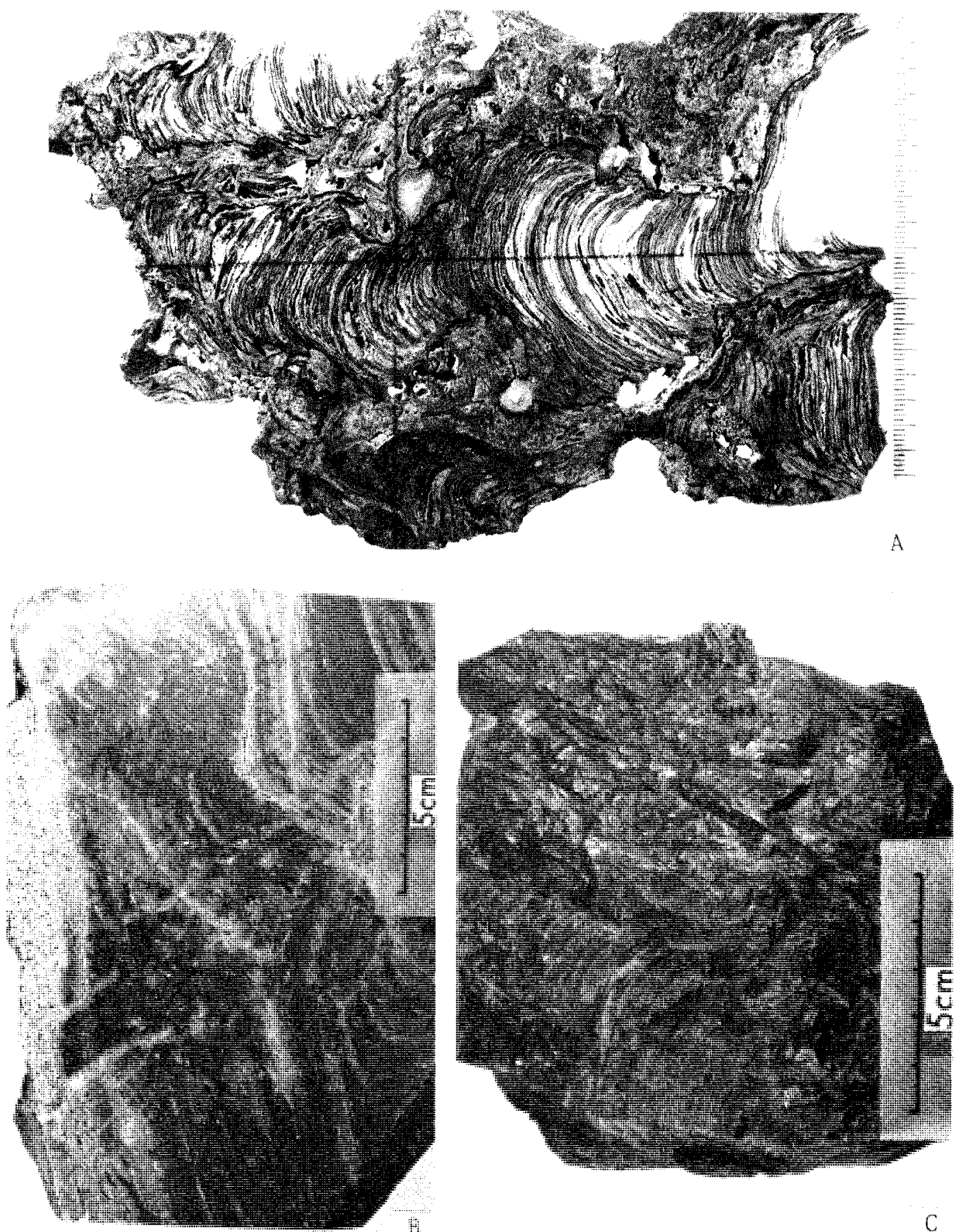

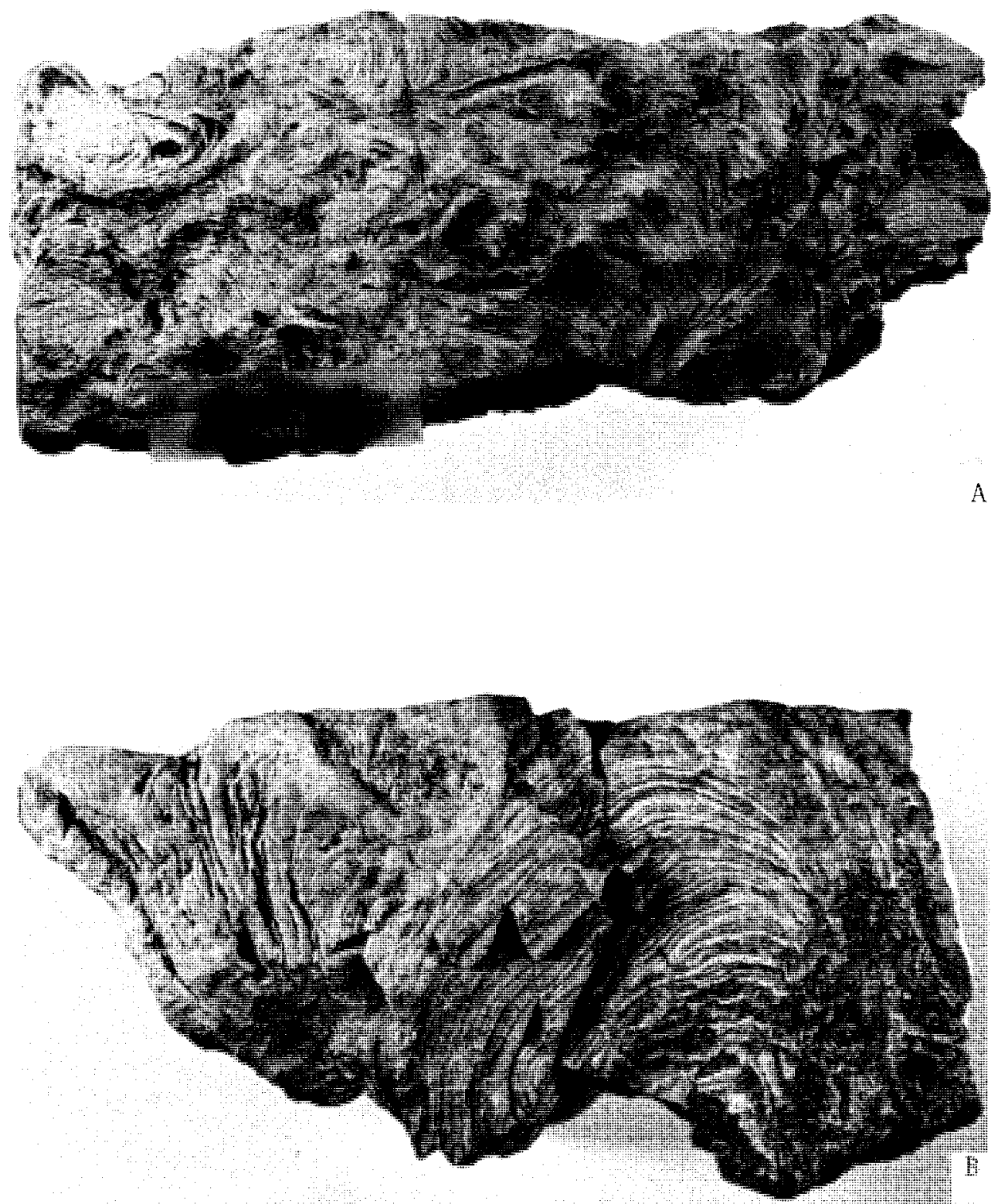

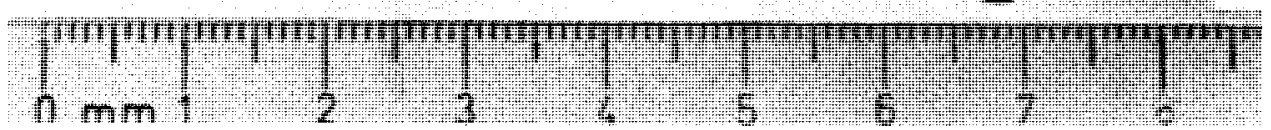


B.J. Griffin and W.V. Preiss
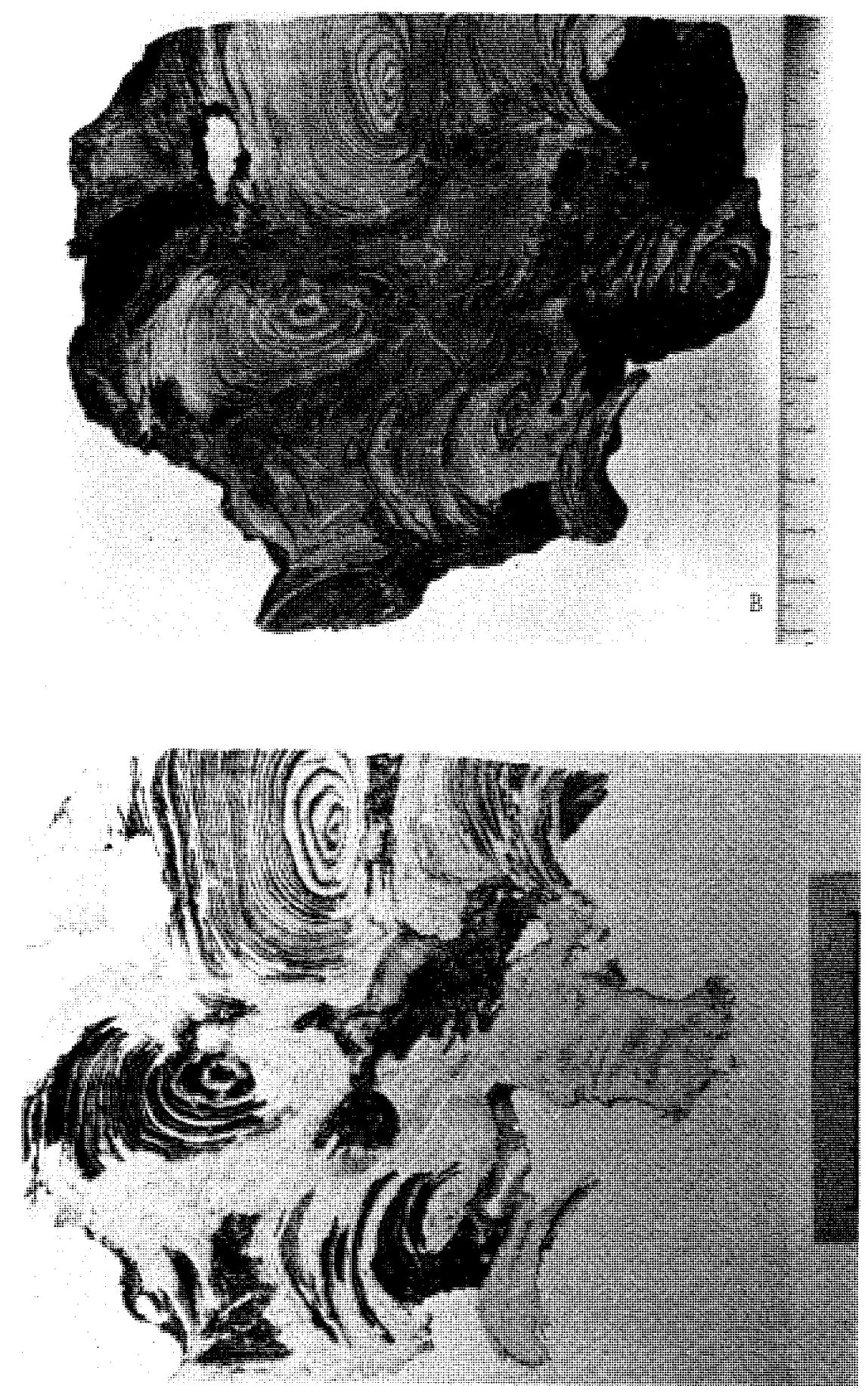

PLATE 4 

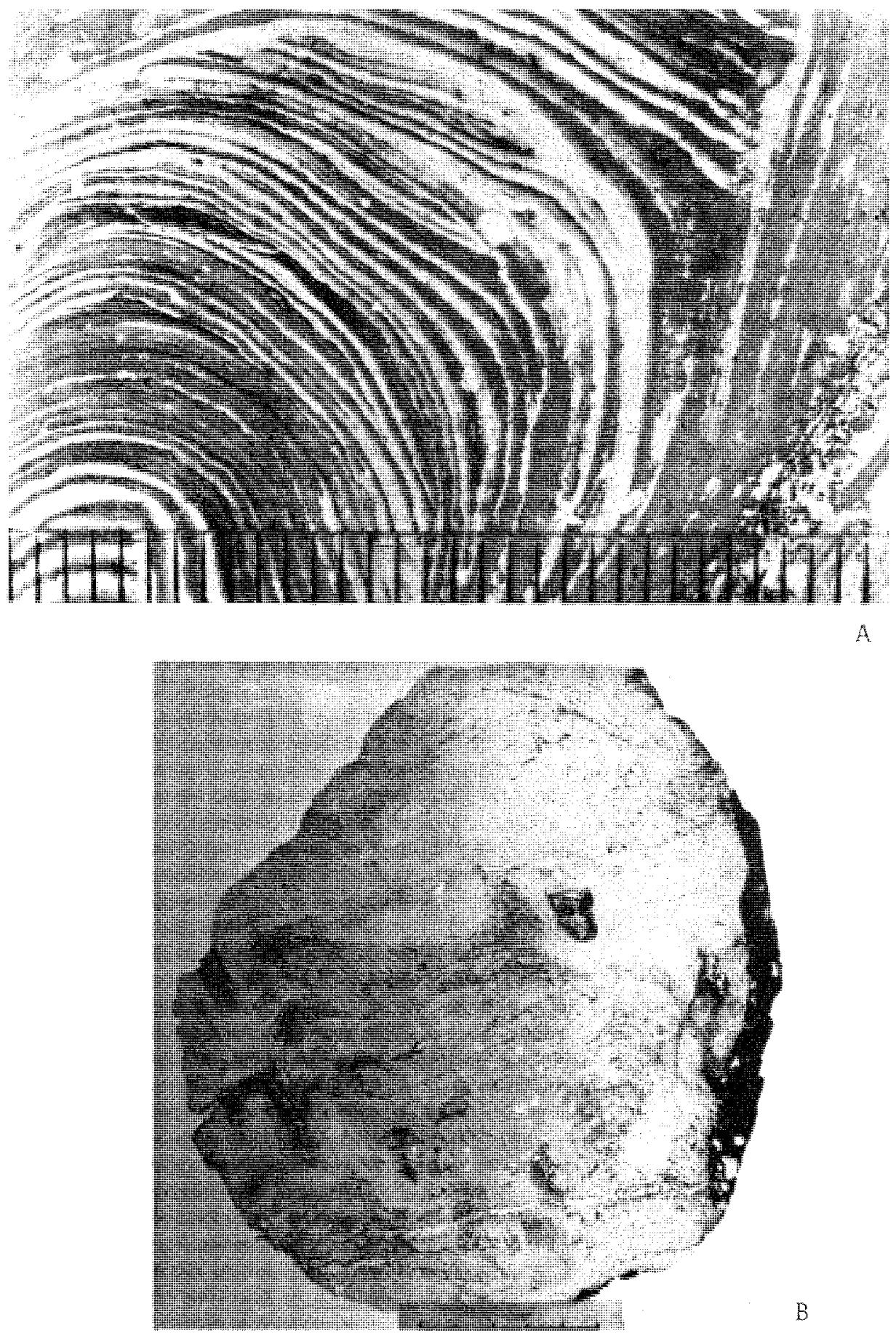
B.J. Griffin and W.V. Preiss
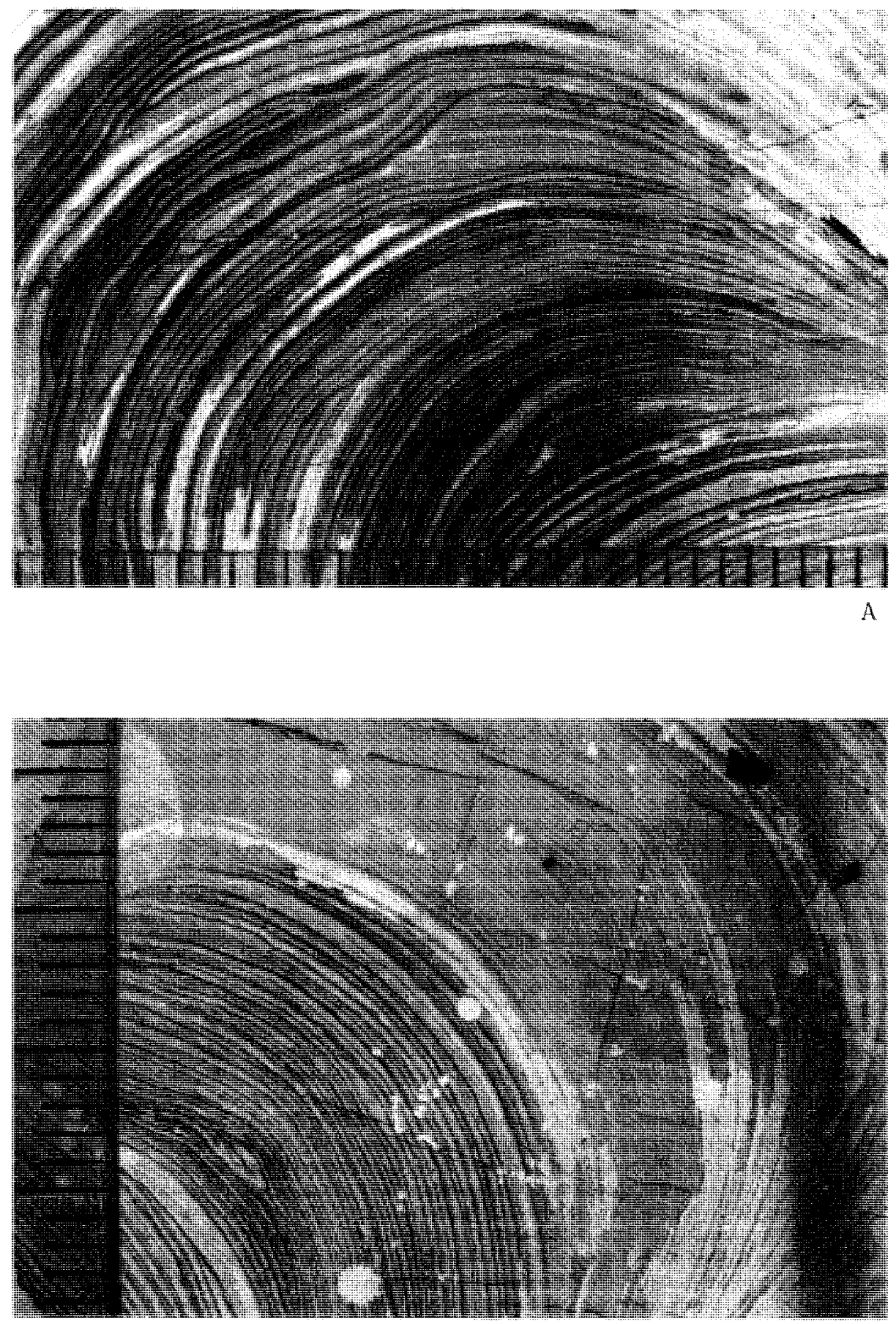
